\title{
Trophic basis of production of stream detritivores shifts with reduced forest inputs
}

\author{
Susan L. Eggert $\mathbb{D} \cdot$ J. Bruce Wallace $\cdot$ Judy L. Meyer $\cdot$ Jackson R. Webster
}

Received: 25 September 2019/Revised: 23 May 2020/Accepted: 27 May 2020/Published online: 6 June 2020

(C) This is a U.S. government work and not under copyright protection in the U.S.; foreign copyright protection may apply 2020

\begin{abstract}
Estimating changes in organic matter flow from resource to consumer using trophic basis of production (TBP) is a way to examine resource limitation effects on ecosystem function. We examined diet shifts and production of insect detritivores to assess changes with reduced detrital inputs to a forested headwater stream. Organic matter was excluded for 7 years using a canopy net. Small and large wood were removed from the stream after the $3 \mathrm{rd}$ and 5th year, respectively. Detritivore production
\end{abstract}

Handling editor: Marcelo S. Moretti

Electronic supplementary material The online version of this article (https://doi.org/10.1007/s10750-020-04317-8) contains supplementary material, which is available to authorized users.

S. L. Eggert (四)

USDA Forest Service, Northern Research Station, Grand Rapids, MN 55744, USA

e-mail: sue.1.eggert@usda.gov

S. L. Eggert · J. B. Wallace

Department of Entomology, University of Georgia,

Athens, GA 30602, USA

J. B. Wallace · J. L. Meyer

Odum School of Ecology, University of Georgia, Athens,

GA 30602, USA

\section{J. R. Webster}

Department of Biological Sciences, Virginia Polytechnic Institute and State University, Blacksburg,

VA 24061, USA declined after 3 years of litter exclusion. After wood removal, production of detritivores declined again. Steepest declines in Pycnopsyche gentilis production occurred within year 1. Tipula spp. and Tallaperla spp. production declined after wood removal. Diets shifted from leaves to wood to fine particulate organic matter (FPOM) for Tipula spp. and Tallaperla spp., but not for $P$. gentilis. Resource flows to detritivores shifted in the exclusion stream from leaves to wood to FPOM after leaf standing crops declined and wood removal. Small wood was an important food resource. TBP results showed shifts in food resource use by two detritivores with terrestrial input reduction. These findings suggest that maintaining diverse riparian inputs of organic matter is important for detritivore productivity in forested headwater watersheds.

Keywords Organic matter · Detritus · Gut contents · Freshwater invertebrate $\cdot$ Riparian $\cdot$ Flow food web

\section{Introduction}

In forested headwater streams, the majority of energy inputs are detrital (e.g., Fisher \& Likens, 1973; Webster \& Meyer, 1997). Positive relationships between terrestrially derived organic matter and stream invertebrate productivity have been demonstrated in a long-term exclusion of allochthonous 
inputs to a headwater stream (e.g., Wallace et al., 1997, 1999, 2015) and short-term leaf litter additions (e.g., Richardson, 1991). Leaf litter is the preferred food resource for many stream invertebrates, but may become scarce during certain times of the year (e.g., Grubbs \& Cummins, 1996). Wood without biofilm is a less-palatable source of carbon, but with its epixylic biofilm of amorphous detritus, fungi, and bacteria, can also be an important food resource for some invertebrates (e.g., Tank \& Winterbourn, 1996; Eggert \& Wallace, 2007). The physical structure of wood makes it a long-lasting resource for microbes and invertebrates alike (e.g., Benke, 1985; Hax \& Golladay, 1993; Tank et al., 1993). Fine particulate organic matter (FPOM) stored in the stream may serve as an additional detrital resource (e.g., Tank \& Winterbourn, 1995).

The trophic basis of production calculation traces organic matter flow between resources and consumers in a food web, making it a useful tool to quantify the strength of resource-consumer linkages in ecosystems (e.g., Benke \& Wallace, 1980, 1997; Benke et al., 2001; Benke, 2018), describe the energy base of streams (e.g., Smock \& Roeding, 1986), and demonstrate alterations of organic matter flow with changes in food resources (e.g., Hall et al., 2000; Rosi-Marshall \& Wallace, 2002). The method relies on estimates of secondary production, resources consumed, and assimilation of resources by consumers (Benke \& Wallace, 1980). Our objective here was to use the trophic basis of production method to assess changes in resource use among detritivores in response to a long-term, whole-stream manipulation of detrital resources.

The experimental exclusion of litter inputs to an Appalachian headwater stream and the subsequent removal of wood altered the resource base of the stream (Wallace et al., 1997, 1999, 2015). Leaf litter standing crops declined quickly in the exclusion stream, but alternate food resources such as wood and fine particulate organic matter (FPOM) remained abundant after 3 years of litter exclusion (Eggert et al., 2012). We used the trophic basis of production method to quantify changes in organic matter flow associated with a step-wise reduction in detrital resources available to a detritivore assemblage in a headwater stream over an 8-year period. Gut content analyses, invertebrate production estimates, and assimilation efficiencies for various food resources were used to measure effects of riparian disturbance on functioning of the lowest trophic levels. We anticipated shifts in organic matter flows from leaves to wood during initial stages of the litter exclusion and another shift toward amorphous detritus flows (the next largest pool of organic matter remaining) following the removal of wood resources. Additionally, our intent was to differentiate the importance of different detrital resources (i.e., more palatable leaf detritus vs. more refractory wood without biofilm detritus), and to better understand mechanisms of resource partitioning among a guild of stream detritivores.

\section{Methods}

Study sites

The reference and litter exclusion streams draining Catchments 53 and 55, respectively, are located within Coweeta Hydrologic Laboratory in the Blue Ridge province of the southern Appalachian Mountains in western North Carolina. Leaf litter and wood were excluded from $170 \mathrm{~m}$ of the treatment stream from August 1993 to August 2000 using a 2.5-cm mesh gill net canopy over the entire stream and $1-\mathrm{cm}$ mesh bird netting along each bank. The sides of the canopy were open to allow for aerial insect recolonization. The canopy started at the spring-seep, preventing organic matter inputs from upstream. In August 1996, small wood ( $<10 \mathrm{~cm}$ diameter) was removed by hand from the exclusion stream (Wallace et al., 2000). Large wood was removed by hand from the exclusion stream in August 1998 (Wallace et al., 2001). The reference and litter exclusion streams are similar with respect to discharge, thermal regime, elevation, aspect, size, and canopy cover (Electronic Supplementary Material: Table S1). Both watersheds are heavily forested by Quercus spp. (oak), Acer rubrum L. (red maple), Liriodendron tulipifera L. (tulip popular), and dogwood Cornus florida L. (flowering dogwood), with a dense riparian understory of Rhododendron maxima $\mathrm{L}$. (rhododendron), which provides year-round shading.

\section{Study organisms}

We estimated organic matter flows (hereafter referred to as flows) from food resources to insect detritivores using the trophic basis of production calculation 
(Benke \& Wallace, 1980). We focused on the dominant $(54-77 \%$ of shredder production) shredders Pycnopsyche gentilis (McLachlan, 1871) (caddisfly), Tipula spp. (fly), and Tallaperla spp. (stonefly). Additionally, we estimated flows to uncommon shredder taxa Leuctra spp. (stonefly), Lepidostoma spp. (caddisfly), Molophilus spp. (fly), Fattigia pele (Ross, 1938) (caddisfly), Psilotreta spp. (caddisfly), Limonia spp. (fly), Anchytarsus spp. (beetle) and Lipsothrix spp. (fly); hereafter referred to as 'other shredders.' We measured secondary production for each of the rare shredders and estimated diets based on the mean diets of the three dominant shredders. Mean annual organic matter flows from each food resource to the study organisms were calculated for each stream for the pre-treatment period (1992-1993), the litter exclusion only period (1993-1994, 1994-1995, and 1995-1996), the period following small wood removal (1996-1997 and 1997-1998), and the period after large wood removal (1998-1999 and 1999-2000).

\section{Annual production}

Invertebrate biomass was estimated for mixed substrate $\left(400-\mathrm{cm}^{2}\right.$ corer) and bedrock outcrop habitats $\left(225-\mathrm{cm}^{2}\right.$ area scraped) in the reference and litter exclusion stream. Four samples from mixed substrates and three samples from bedrock outcrops were collected monthly from 1992 to 2000 . Invertebrates were separated into $>1 \mathrm{~mm}$ and $<1 \mathrm{~mm}>250 \mu \mathrm{m}$ size fractions and preserved in $7 \%$ formalin. All organisms were sorted under a dissecting microscope $(15 \times)$, identified to genus, and measured to the nearest $\mathrm{mm}$. Invertebrates in the smaller size fraction were subsampled if necessary. Annual production was calculated using size frequency methods described in Wallace et al. (1999) and Electronic Supplementary Material 1. The size frequency method has been used successfully since 1984 to estimate secondary production in these streams (Wallace et al., 2015). Habitat-weighted production was calculated by multiplying annual production by the proportion of habitat type in each stream. The small pre-treatment sample size ( $n=1)$ precluded the use of Before After Control Impact (BACI) analysis (Stewart-Oaten et al., 1986) to statistically determine time series differences in annual production.
Gut analyses

Pycnopsyche gentilis, Tipula spp., and Tallaperla spp. individuals were collected seasonally (autumn = September, October, November; winter $=$ December, January, February; spring = March, April, May; summer = June, July, August) from each site from spring 1993 to summer 2000. Three to five similar-sized individuals of each taxon were examined seasonally for each stream. A minimum sample size of three was determined by calculating a coefficient of variation of percent food type consumed for various sample sizes of individuals of a taxon. Individuals of each taxon were not found during every seasonal collection. Diets of organisms collected seasonally were examined by measuring the relative area of particles of each food type in the guts using the methods of Cummins (1973). The proportional area of each food type (leaf detritus, wood, amorphous detritus, animal, diatoms, fungi, and miscellaneous which included moss) was calculated for each individual. The proportion of each food type consumed by each of the three dominant shredders was calculated seasonally and annually. Differences in gut contents of shredders between streams "before" and "after" each experimental manipulation were compared using BACI analysis (Stewart-Oaten et al., 1986). Differences in seasonal proportions of leaf, wood, and amorphous detritus in diets within and among shredder taxa were also analyzed using ANOVA (SigmaPlot v13). Data were arcsine transformed and checked for normality and equal variance.

Trophic basis of production

Using the methods of Benke \& Wallace (1980), we calculated trophic basis of production calculations from empirical measures of production and diet composition of taxa, along with estimates of assimilation efficiencies and net production efficiencies taken from the literature. We calculated the relative amount of production derived from each food type, the percent contribution of each food type to consumer diets, and the amount of each food type ingested by each consumer (detailed methods in Electronic Supplementary Material 1). Annual organic matter flows for each food type were calculated for P. gentilis, Tallaperla spp., Tipula spp., and other shredders by 
averaging seasonal proportions of food types for each of the dominant taxa.

\section{Results}

Secondary production

Pycnopsyche gentilis, Tallaperla spp., and Tipula spp. together represent $68 \%$ of the annual habitat-weighted production of shredders in the two streams during nontreatment years (Electronic Supplementary Material; Table S2). Production of the three taxa combined declined to $54 \%$ of pre-treatment levels after 3 years of litter exclusion. After small and large wood removal and 7 years of litter exclusion, only $9 \%$ of pretreatment $P$. gentilis, Tallaperla spp., and Tipula spp. production remained in the exclusion stream. Shredder taxa were differentially affected by the detritus manipulations. After 1 year of litter exclusion, $P$. gentilis production was $20 \%$ of pre-treatment levels and eventually declined to less than $1 \%$ (Fig. 1a). In

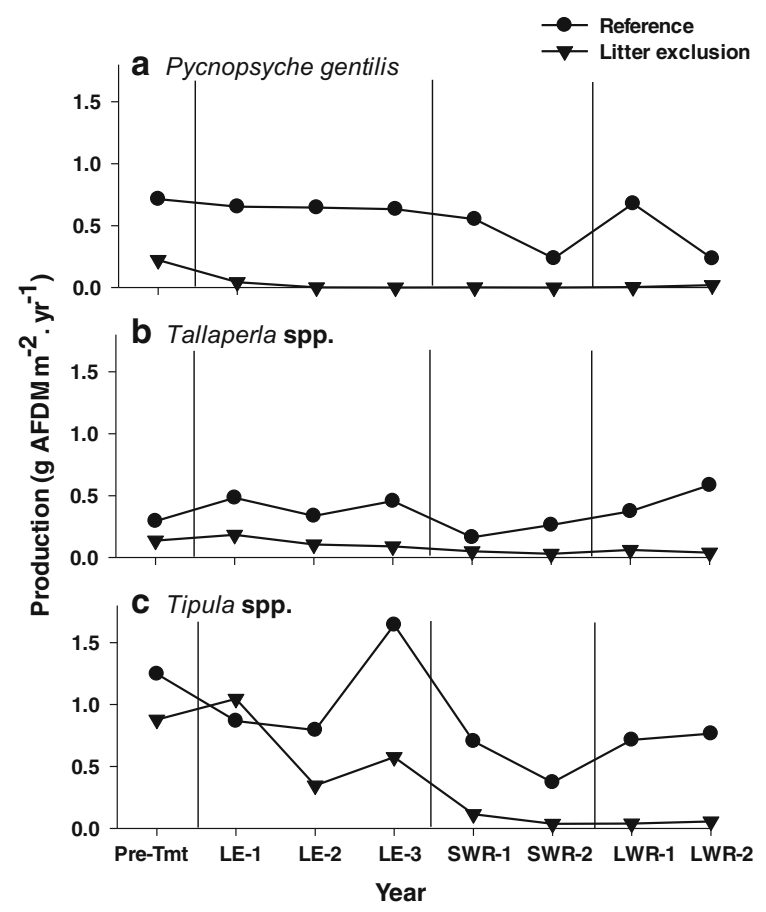

Fig. 1 Annual habitat-weighted production of a P. gentilis, b Tallaperla spp., and c Tipula spp. in the reference and litter exclusion streams from August 1992 to August 2000. Vertical lines represent start of litter exclusion (LE-1), small wood (SWR-1), and large wood (LWR-1) removal in treatment stream contrast, Tallaperla spp. and Tipula spp. production increased by $34 \%$ and $19 \%$, respectively, during year 1 of litter exclusion (Electronic Supplementary Material; Table S2). Production of these two taxa later declined following wood removal but did not decrease as rapidly as $P$. gentilis production (Fig. 1b, c).

\section{Diet Shifts}

Dominant shredders responded differently to the organic matter manipulations with regard to changes in the proportion of food types consumed. Leaf material dominated the diet of $P$. gentilis in the reference and litter exclusion stream (75-100\%) throughout the study (Table 1, Electronic Supplementary Material; Table S3). There was no diet shift by $P$. gentilis in the exclusion stream following the start of litter exclusion (Table 1, Electronic Supplementary Material; Table S3). In contrast, we observed significant diet shifts for Tallaperla spp. and Tipula spp. in the litter exclusion stream. The proportion of leaf material in the gut contents of Tallaperla spp. in the litter exclusion stream decreased significantly $(P<0.01$, BACI $)$ compared to the reference stream during years 1-3 of litter exclusion (Table 1, Electronic Supplementary Material; Table S3). Concurrently, the proportion of wood in the diet increased $(P<0.01$, BACI $)$. The proportion of wood in the diet of Tallaperla spp. did not differ between streams after we removed small wood, but there was a significant increase in the proportion of amorphous detritus in the guts of individuals living in the litter exclusion stream after we removed large wood $(P<0.001, \mathrm{BACI})$. The same pattern held true for Tipula spp. found in the litter exclusion stream (Table 1, Electronic Supplementary Material; Table S3). Seasonal diets within taxa were not significantly different using ANOVA (Electronic Supplementary Material; Table S4).

Trophic Basis of Production

Total annual organic matter consumption of the shredder community in the reference stream ranged from 16 to $32 \mathrm{~g} \mathrm{AFDM} \mathrm{m}^{-2}$ year $^{-1}$ over the 8-year period (Table 2). Leaf material dominated flows to shredders (65-74\%) with a smaller proportion of wood and amorphous detritus flows. In the litter exclusion stream, total organic matter consumption was highest (14.2 $\mathrm{g} \mathrm{AFDM} \mathrm{m}^{-2}$ year $^{-1}$ ) during the pre-treatment 
Table 1 Dominant food types (mean $\% \pm 1 \mathrm{SE}$ ) consumed by Pycnopsyche gentilis, Tallaperla spp., and Tipula spp. in reference and litter exclusion streams during each treatment period

\begin{tabular}{|c|c|c|c|c|c|c|c|c|}
\hline \multirow[t]{2}{*}{ Food type } & \multicolumn{2}{|c|}{ Pre-treatment } & \multicolumn{2}{|c|}{ Litter exclusion } & \multicolumn{2}{|c|}{ Small wood removal } & \multicolumn{2}{|c|}{ Large wood removal } \\
\hline & Reference & Exclusion & Reference & Exclusion & Reference & Exclusion & Reference & Exclusion \\
\hline \multicolumn{9}{|l|}{ P. gentilis $^{\mathrm{a}}$} \\
\hline Leaves & $81.1(7.5)$ & $85.9(4.4)$ & $87.8(2.7)$ & 82.4 & $92.5(1.8)$ & $67.3(1.9)$ & $87.9(2.9)$ & $92.8(6.9)$ \\
\hline Wood & $13.5(5.5)$ & $6.3(3.2)$ & $3.8(1.2)$ & 0.0 & $3.1(1.5)$ & $10.5(10.5)$ & $3.3(1.7)$ & $0.0(0.0)$ \\
\hline \multicolumn{9}{|l|}{ Amorphous } \\
\hline Detritus & $4.9(1.9)$ & $6.7(1.8)$ & $7.6(1.9)$ & 17.6 & $3.5(1.0)$ & $21.8(9.0)$ & $6.5(1.8)$ & $7.0(6.8)$ \\
\hline \multicolumn{9}{|c|}{ Tallaperla spp. } \\
\hline Leaves & $46.3(9.7)$ & $71.0(8.0)$ & $60.1(7.5)$ & $29.8(6.2)^{* *}$ & $45.1(10.3)$ & $4.7(2.4)^{* * * *}$ & $56.0(10.0)$ & $1.4(1.0)^{* * *}$ \\
\hline Wood & $40.4(10.6)$ & $17.0(8.7)$ & $11.1(3.0)$ & $40.0(7.1)^{* *}$ & $28.4(7.7)$ & $44.0(7.8)$ & $13.5(5.2)$ & $10.2(4.0)$ \\
\hline \multicolumn{9}{|l|}{ Amorphous } \\
\hline Detritus & $11.1(1.6)$ & $10.4(2.1)$ & $27.0(6.0)$ & $27.4(7.5)$ & $24.9(4.9)$ & $47.0(8.4)$ & $26.6(7.7)$ & $80.2(3.5)^{* * *}$ \\
\hline \multicolumn{9}{|l|}{ Tipula spp. } \\
\hline Leaves & $58.0(3.5)$ & $62.7(10.0)$ & $65.7(4.4)$ & $29.0(5.8)^{*}$ & $59.1(6.8)$ & $11.1(4.6)^{*}$ & $73.8(7.6)$ & $18.7(17.2)^{*}$ \\
\hline Wood & $27.3(6.6)$ & $27.1(8.7)$ & $21.7(3.8)$ & $59.6(5.7)^{*}$ & $29.7(5.1)$ & $46.6(12)$ & $16.3(7.8)$ & $21.7(8.4)$ \\
\hline \multicolumn{9}{|c|}{ Amorphous } \\
\hline Detritus & $11.1(1.7)$ & $9.1(1.9)$ & $10.1(2.3)$ & $9.6(2.2)$ & $10.0(2.5)$ & 31.8 (13.0) & $8.3(1.8)$ & $51.9(11.2)^{*}$ \\
\hline
\end{tabular}

Pre-treatment year (Sept. 1992-Aug. 1993), Litter exclusion represents years 1, 2, and 3 (Sept. 1993-Aug. 1996), Small wood removal represents years 4 and 5 (Sept. 1996-Aug. 1998), Large wood removal represents years 6 and 7 (Sept. 1998-Aug. 2000) $* P<0.05, * * P<0.01, * * * P<0.001, \mathrm{BACI}$

${ }^{\text {a }}$ Sample size for $P$. gentilis in litter exclusion stream after pre-treatment: LE, $n=1$; SWR, $n=2$; LWR, $n=2$

Table 2 Total annual consumption rates in $\mathrm{g}$ AFDM m ${ }^{-2}$ year $^{-1}$ (percent of total in parentheses) for P. gentilis, Tallaperla spp., Tipula spp., and other shredders in reference and litter exclusion streams averaged over each treatment period

\begin{tabular}{|c|c|c|c|c|c|c|c|c|}
\hline \multirow[t]{2}{*}{ Food type } & \multicolumn{2}{|c|}{ Pre-treatment } & \multicolumn{2}{|c|}{ Litter exclusion } & \multicolumn{2}{|c|}{ Small wood removal } & \multicolumn{2}{|c|}{ Large wood removal } \\
\hline & Reference & Exclusion & Reference & Exclusion & Reference & Exclusion & Reference & Exclusion \\
\hline Leaves & $15.93(65)$ & $9.96(70)$ & $23.34(73)$ & $1.33(26)$ & $11.34(70)$ & $0.13(13)$ & $19.02(74)$ & 0.31 (19) \\
\hline Wood & $5.78(24)$ & $2.82(20)$ & $4.21(13)$ & $2.84(56)$ & 3.08 (19) & $0.45(46)$ & $2.86(11)$ & $0.19(12)$ \\
\hline \multicolumn{9}{|l|}{ Amorphous } \\
\hline Detritus & $2.12(9)$ & $1.22(9)$ & $4.03(13)$ & $0.76(15)$ & $1.67(10)$ & $0.32(32)$ & $3.40(13)$ & $1.00(62)$ \\
\hline Diatoms & $0.02(0)$ & $0.02(0)$ & $0.03(0)$ & $0.01(0)$ & $0.01(0)$ & $0.01(1)$ & $0.01(0)$ & $0.00(0)$ \\
\hline Fungi & $0.16(1)$ & $0.13(1)$ & $0.09(0)$ & $0.04(1)$ & $0.07(0)$ & $0.02(2)$ & $0.07(0)$ & $0.01(1)$ \\
\hline Misc. & $0.36(1)$ & $0.02(0)$ & $0.38(1)$ & $0.05(1)$ & $0.10(1)$ & $0.06(6)$ & $0.49(2)$ & $0.11(7)$ \\
\hline Total & 24.36 & 14.18 & 32.08 & 5.03 & 16.27 & 0.98 & 25.85 & 1.62 \\
\hline
\end{tabular}

Pre-treatment year (Sept. 1992-Aug. 1993), Litter exclusion represents years 1, 2, and 3 (Sept. 1993-Aug. 1996), Small wood removal represents years 4 and 5 (Sept. 1996-Aug. 1998), Large wood removal represents years 6 and 7 (Sept. 1998-Aug. 2000)

year, and leaf detritus dominated all flows (70\%) (Table 2). Wood consumption was similar in the reference and litter exclusion streams. With the start of litter exclusion, however, the magnitude and distribution of the flows among the food types changed. Total consumption of all food types in the exclusion stream 
declined to $5 \mathrm{~g} \mathrm{AFDM} \mathrm{m}^{-2}$ year $^{-1}$ after 3 years of litter exclusion and less than $1 \mathrm{~g} \mathrm{AFDM} \mathrm{m}^{-2}$ year $^{-1}$ after small wood removal (Table 2). During the litter exclusion period, the proportion of flows from wood increased from $20 \%$ during the pre-treatment year to $56 \%$. Flows from leaves to consumers decreased with each experimental period with the exception of the large wood removal (Table 2). Over the 8-year study, leaf consumption declined by $63-81 \%$ compared to pre-treatment values. After small and large wood removal, the proportion of flows from wood to shredder consumers declined to $12 \%$, while the proportion of flows from amorphous detritus increased from 9 to $62 \%$. We did not observe any increase in flows from diatoms to shredder consumers, although several Tipula spp. collected from the litter exclusion stream during the wood removal periods had unusually high proportions of aquatic moss in their guts.

Food webs tracing organic matter flow from resource to consumer illustrate the changes in flow magnitudes for each treatment period in each stream (Figs. 2, 3, 4, 5, Electronic Supplementary Material; Table S5). The largest organic matter flows in the reference stream were from leaf detritus to $P$. gentilis and "other shredders" (Figs. 2, 3, 4, 5, Electronic Supplementary Material; Table S5). Prior to litter exclusion, the largest flows in the exclusion stream were from leaf detritus to Tipula spp. (Figure 2b, Electronic Supplementary Material; Table S5). After litter exclusion started, the largest flows in the

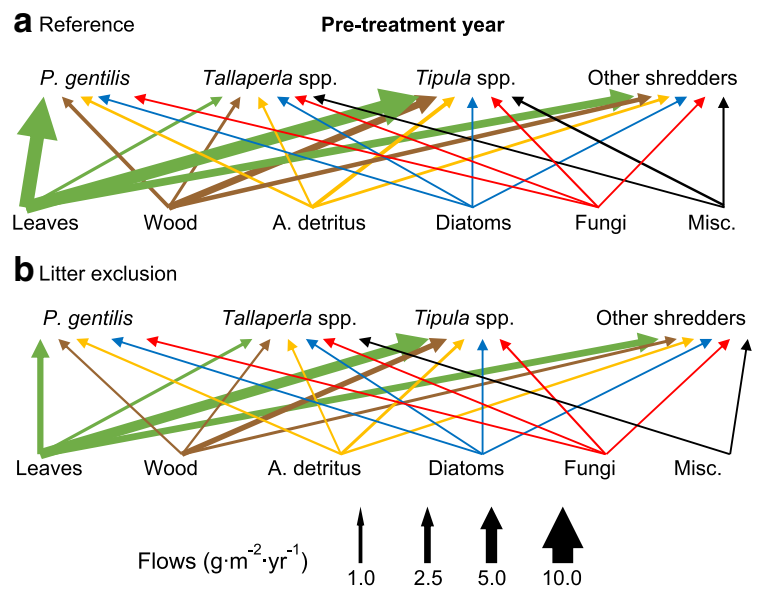

Fig. 2 Mean annual consumption rates (g AFDM m ${ }^{-2}$ year $^{-1}$ ) for shredders in a reference and $\mathbf{b}$ litter exclusion stream for pretreatment year (Sept. 1992-Aug. 1993). Width of the arrows is proportional to the magnitude of the flow

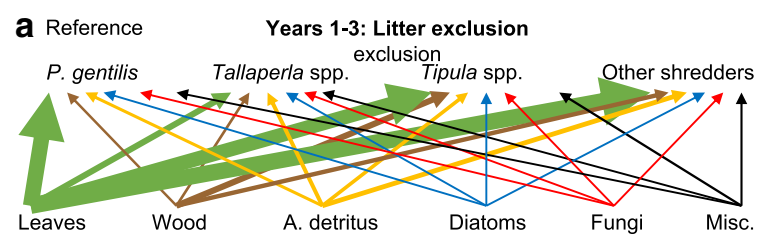

b Litter exclusion

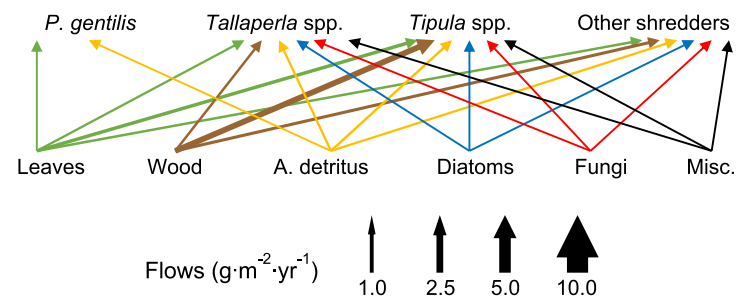

Fig. 3 Mean annual consumption rates ( $\mathrm{g} \mathrm{AFDM} \mathrm{m}^{-2}$ year $^{-1}$ ) for shredders in a reference and $\mathbf{b}$ litter exclusion stream for litter exclusion: years 1, 2, and 3 (Sept. 1993-Aug. 1996). Width of the arrows is proportional to the magnitude of the flow

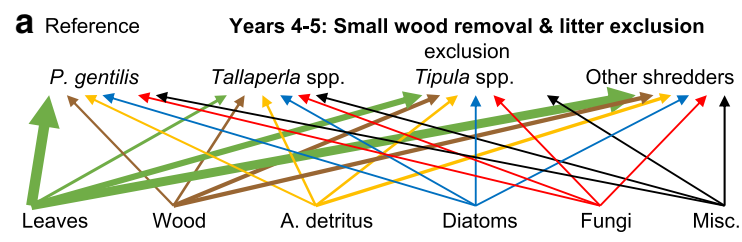

b Litter exclusion

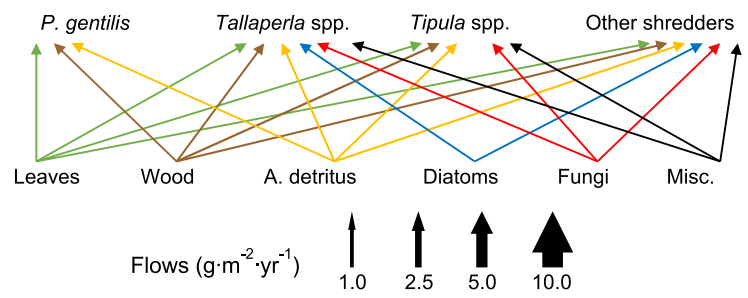

Fig. 4 Mean annual consumption rates ( $\mathrm{g} \mathrm{AFDM} \mathrm{m}^{-2}$ year $^{-1}$ ) for shredders in $\mathbf{a}$ reference and $\mathbf{b}$ litter exclusion stream for small wood removal and litter exclusion: years 4 and 5 (Sept. 1996-Aug. 1998). Width of the arrows is proportional to the magnitude of the flow

exclusion stream were from wood to Tipula spp. (Figure 3b, Electronic Supplementary Material; Table S5). The amount of wood consumed also increased for Tallaperla spp. and other shredders. After small wood removal, the amount of wood consumed by each shredder taxon in the exclusion stream was smaller than in the reference stream (Fig. 4, Electronic Supplementary Material; Table S5). Flows from amorphous detritus to Tallaperla spp. were highest in the litter exclusion stream following 


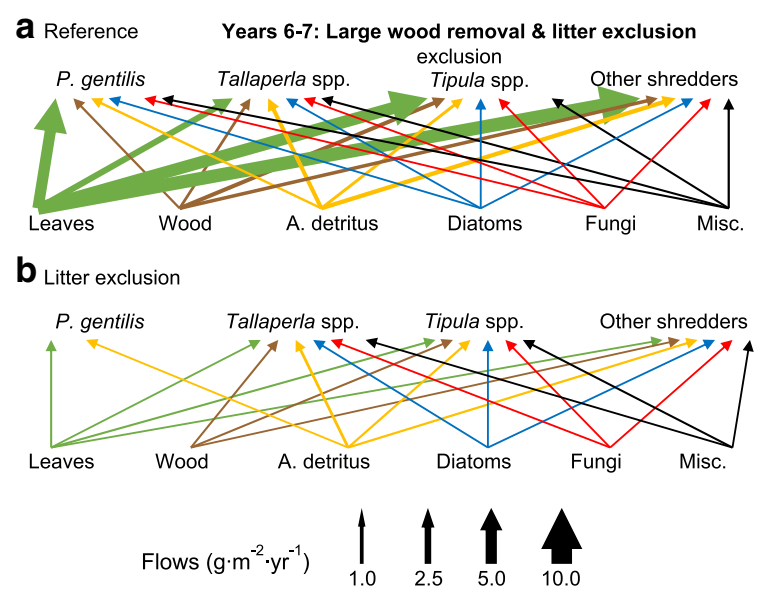

Fig. 5 Mean annual consumption rates (g AFDM m ${ }^{-2}$ year $^{-1}$ ) for shredders in a reference and $\mathbf{b}$ litter exclusion stream for large wood removal and litter exclusion: years 6 and 7 (Sept. 1998-Aug. 2000). Width of the arrows is proportional to the magnitude of the flow

large wood removal (Fig. 5, Electronic Supplementary Material; Table S5). The amount of fungi, diatoms, and miscellaneous material consumed by shredders was never large for either stream. In the litter exclusion stream, however, Tallaperla spp. consumed more fungi the first 3 years after the start of litter exclusion than before exclusion (Figs. 2, 3, Electronic Supplementary Material; Table S5). Flows from fungi to Tallaperla spp. declined after wood removal (Figs. 4, 5, Electronic Supplementary Material; Table S5). A similar pattern occurred for Tipula spp. in the exclusion stream, except that fungal consumption during the first years of litter exclusion was about half of that consumed prior to litter exclusion (Figs. 2, 3, 4, 5, Electronic Supplementary Material; Table S5).

Leaf detritus accounted for $41-59 \%$ of shredder production in the reference stream and $6-46 \%$ of shredder production in the litter exclusion stream (Table 3). Since experimental assimilation efficiencies for wood and its associated biofilm were greater than assimilation efficiencies for leaves (see Eggert \& Wallace, 2007), total annual shredder production attributable to wood in the reference stream $(0.8-1.6$ g AFDM m ${ }^{-2}$ year $^{-1}$ ) was similar to that for leaf material (0.9-1.8 $\mathrm{g} \mathrm{AFDM} \mathrm{m}^{-2}$ year $^{-1}$ ). After litter exclusion began in the treatment stream, the proportion of production attributable to leaves decreased from 46 to $10 \%$, while the proportion of shredder production attributable to wood increased from 49 to
$85 \%$ (Table 3). The proportion of production due to wood declined to $42 \%$ following the removal of both small and large wood, but still remained higher than the proportion of production attributed to amorphous detritus (36\%). Amorphous detritus accounted for $4-7 \%$ of shredder production in the reference stream throughout the 8-year period.

Leaf detritus supported the majority of $P$. gentilis production in the reference stream throughout the study, while production of Tipula spp. and Tallaperla spp. depended equally on wood and leaves (Electronic Supplementary Material; Table S6). Shifts in Tipula spp. and Tallaperla spp. production attributable to various resources in the litter exclusion stream paralleled resource consumption patterns. Tipula spp. and Tallaperla spp. production associated with wood increased during the first 3 years of litter exclusion, followed by an increase of production derived from amorphous detritus after all wood was removed.

\section{Discussion}

Our results showed a clear shift within the detrital resource base of the litter exclusion stream from leaves to wood to amorphous detritus with each reduction in food resources. Detritivores differed in their response to changes in food availability. Production of $P$. gentilis decreased more rapidly than Tipula spp. and Tallaperla spp. production. The increase in production of these latter two taxa during the first year of litter exclusion was surprising, although year-to-year variability in detritivore production is not unexpected in these streams (Lugthart \& Wallace, 1992). In the reference stream, production of Tallaperla spp. also increased during year 1 of the experiment. Given the sharp decrease in leaf inputs to the litter exclusion stream during year 1, however, we did not expect Tallaperla spp. production to increase at all and leads to the question of why certain taxa were less affected by the series of resource reductions.

\section{Resource availability}

Our data suggest that the patterns of detritivore production could be explained by the availability of alternate food resources and the ability of some taxa to switch to these alternate resources. Food availability often is the most important factor limiting the 
Table 3 Total annual production in $\mathrm{g}$ AFDM $\mathrm{m}^{-2}$ year $^{-1}$ attributable to each food type (percent of total in parentheses) for $P$. gentilis, Tallaperla spp., Tipula spp., and other shredders in reference and litter exclusion streams averaged over each treatment period

\begin{tabular}{|c|c|c|c|c|c|c|c|c|}
\hline \multirow[t]{2}{*}{ Food type } & \multicolumn{2}{|c|}{ Pre-treatment } & \multicolumn{2}{|c|}{ Litter exclusion } & \multicolumn{2}{|c|}{ Small wood removal } & \multicolumn{2}{|c|}{ Large wood removal } \\
\hline & Reference & Exclusion & Reference & Exclusion & Reference & Exclusion & Reference & Exclusion \\
\hline Leaves & $1.185(41)$ & $0.741(46)$ & $1.811(56)$ & $0.099(10)$ & $0.879(48)$ & $0.010(6)$ & $1.487(59)$ & $0.023(17)$ \\
\hline Wood & $1.580(54)$ & $0.803(49)$ & $1.184(36)$ & $0.828(85)$ & $0.869(47)$ & $0.130(80)$ & $0.808(32)$ & $0.058(42)$ \\
\hline \multicolumn{9}{|l|}{ Amorphous } \\
\hline Detritus & $0.106(4)$ & $0.061(4)$ & $0.202(7)$ & $0.379(4)$ & $0.084(5)$ & $0.016(10)$ & $0.170(7)$ & $0.050(36)$ \\
\hline Diatoms & $0.003(0)$ & $0.003(0)$ & $0.005(0)$ & $0.002(0)$ & $0.002(0)$ & $0.001(1)$ & $0.001(0)$ & $0.000(0)$ \\
\hline Fungi & $0.024(1)$ & $0.020(1)$ & $0.013(0)$ & $0.007(1)$ & $0.010(0)$ & $0.002(1)$ & $0.010(1)$ & $0.002(1)$ \\
\hline Misc. & $0.018(0)$ & $0.001(0)$ & 0.019 (1) & $0.002(0)$ & $0.005(0)$ & $0.003(2)$ & $0.024(1)$ & $0.005(4)$ \\
\hline Total & 2.915 & 1.628 & 3.234 & 0.976 & 1.849 & 0.163 & 2.501 & 0.138 \\
\hline
\end{tabular}

Pre-treatment year (Sept. 1992-Aug. 1993) in both streams, Litter exclusion represents years 1, 2, and 3 (Sept. 1993-Aug. 1996) in both streams, Small wood removal represents years 4 and 5 (Sept. 1996-Aug. 1998) in both streams, Large wood removal represents years 6 and 7 (Sept. 1998-Aug. 2000) in both streams

abundance of animals (White, 1978). Leaf and wood detritus in these streams make up $10 \%$ and $30 \%$, respectively, of the annual AFDM organic matter standing crop (Eggert et al., 2012). Leaf inputs range from 536 to $689 \mathrm{~g} \mathrm{AFDM} \mathrm{m}^{-2}$ year $^{-1}$ (Eggert et al., 2012), while small wood inputs $(<10 \mathrm{~cm}$ diameter) average $160 \mathrm{~g} \mathrm{AFDM} \mathrm{m}^{-2}$ year $^{-1}$ (Wallace et al., 2000). Wood biofilm is also a highly assimilable food resource for detritivores, which makes up $6 \%$ of the AFDM of small wood (Eggert \& Wallace, 2007). Fine particulate organic matter (FPOM),$<1 \mathrm{~mm}$ diameter amorphous detritus, made up $60 \%$ of the organic matter standing crop (Eggert et al., 2012). Periphyton made up the smallest fraction of food resources.

Most of the original food resources available to detritivores had been eliminated from the exclusion stream by the end of the 8 th year. Leaf litter inputs were reduced by $95 \%$ in the litter exclusion stream for the duration of the study (Eggert et al., 2012). We removed $354 \mathrm{~kg}$ AFDM of small wood and $304 \mathrm{~kg}$ AFDM of large wood ( $>10 \mathrm{~cm}$ diameter) from the litter exclusion stream in 1996 and 1998 (Wallace et al., 2000). A source of small wood remained buried in the streambed, which appeared following the scouring of the streambed during storms. Newly exposed wood from the streambed was removed regularly to maintain the treatment. Epixylon was also removed from the pool of detrital resources when small wood was removed in year 4. FPOM standing crops decreased early in the study as material was flushed from the stream bottom with the loss of leaf and wood detritus that served to retain fine organic material (Eggert et al., 2012) and a reduction in FPOM egested by shredder populations. Periphyton was never an abundant food resource available to consumers. Mean annual algal standing crop biomass as chlorophyll $a$ ranged from 0.9 to $5.4 \mathrm{mg} \mathrm{m}^{-2}$ in the reference stream and from 0.9 to $14.1 \mathrm{mg} \mathrm{m}^{-2}$ in the exclusion stream (Eggert et al. unpublished data). Diatoms did not account for a large portion of the gut contents of the dominant detritivore taxa studied here, so it is unlikely that periphyton served as an important food resource.

\section{Detritivore diet shifts}

Changes in the diets of Tipula spp. and Tallaperla spp. with each organic matter manipulation demonstrated the adaptability of those species to changing environmental conditions. Gut contents of $P$. gentilis from each stream showed that $P$. gentilis was an obligate leaf shredder. Mackay \& Kalff (1973) and Hutchens et al. (1997) also found $P$. gentilis consumed only leaf detritus. Although sample sizes were low due to the immediate decline in survivorship after the start of litter exclusion, we found no evidence that $P$. gentilis switched from leaf detritus to other food resources. In contrast, the proportion of wood in the guts of Tipula 
spp. and Tallaperla spp. from the exclusion stream began to increase during the first 3 years of litter exclusion. After the removal of small and large wood from the exclusion stream, we again observed another switch from wood resources to amorphous detritus for Tipula spp. and Tallaperla spp. in the exclusion stream. The decline in wood consumption by Tipula spp. and Tallaperla spp. after small wood removal demonstrates the relative importance of small wood compared to large wood in food webs of forested headwater streams. Small wood, with its high surface area-to-volume ratio (Wallace et al., 2000), supported an alternate food source in the form of epixylon and the wood itself (Eggert \& Wallace, 2007), and served as habitat for Tipula spp. and Tallaperla spp.

Other studies have reported shifts in detritivore resource use. Grubbs \& Cummins (1996) suggested that shredders exhibiting summer growth such as Tallaperla maria and Lepidostoma sp. relied on slowprocessed leaf species and possibly wood during spring and summer months when food became scarce in northern Appalachian mountain streams. Roeding \& Smock (1989) found that leaves supported $84 \%$ of shredder production in a headwater stream of coastal Virginia. They reported that Pycnopsyche luculenta and $P$. scabripennis responded to declining supplies of leaf detritus by shifting their diets to include more wood. Interestingly, they did not observe diet shifts of Tipula spp. when leaves became scarce. Instead Tipula spp. avoided food limitation by aestivating during low resource periods. Hall et al. (2000) quantified organic matter flow through the food webs during two seasons of the first year of litter exclusion in the same streams and found large flows from wood to Tipula spp. following the start of litter exclusion.

Linking resources, species, and ecosystem function

With its high tannin and lignin content, wood without epixylon is probably the most digestion-resistant organic matter source available to detritivores (e.g., Anderson \& Cargill, 1987). Detritivore consumption of wood requires adaptations of mouthpart morphology and digestive physiology (Anderson et al., 1984; Hoffman \& Hering, 2000). Wood consumers must extract bound nitrogen and overcome negative effects of polyphenolics (e.g., Martin et al., 1980). The hindgut of Tipula spp. contains endosymbiotic bacteria (Klug \& Kotarski, 1980) that allow it to efficiently assimilate cellulose (Sinsabaugh et al., 1985). The high alkalinity and proteolytic activity in the midgut of Tipula spp. made it highly efficient at extracting bound proteins (Martin et al., 1980). Gut content analysis of Tipula spp. collected from the reference stream indicated that when leaf standing crops were sufficient, organisms consumed a greater proportion of leaf material compared to wood. However, when leaf standing crops declined during spring and summer seasons, or disappeared completely as in the litter exclusion stream, Tipula spp. switched to wood as a food resource.

Results of a Tallaperla spp. growth study by Tank (1996) suggest that this species grows at similar rates while feeding on wood biofilm or leaf material. Detritivores obtain a portion of their nitrogen by consuming microbes associated with detritus (e.g., Lawson et al., 1984). Epixylon, associated with small wood detritus, contains nitrogen in the form of bacteria and fungi (e.g., Couch \& Meyer, 1992; Tank $\&$ Winterbourn, 1995). Epixylon became more important as a food resource in the litter exclusion stream following the decline in leaf standing crops. Tank \& Webster (1998) and Tank et al. (1998) found greater microbial respiration, extracellular enzyme activity, and fungal biomass on wood in the litter exclusion stream due to higher availability of dissolved nutrients in the absence of leaves. Tallaperla spp. and Tipula spp. were found to assimilate and ingest wood biofilm efficiently, allowing them to utilize epixylon as an alternate food source in the exclusion stream as well as wood without epixylon (Eggert \& Wallace, 2007).

Our experimental removals of organic resources are similar to natural changes in resource availability along a river continuum or with riparian disturbances due to logging, urbanization, or floodplain alterations. In some cases, these disturbances result in reduced detrital inputs due to riparian canopy loss but leave instream wood in place. A reduction in allochthonous inputs caused by the above disturbances would force detritivores to shift diets from preferred resources such as leaf detritus to less digestible resources (e.g., wood without biofilm) to survive. Generalist detritivores in disturbed streams could switch to less-preferred food resources and would seemingly be able to tolerate environmental stressors better than specialist taxa (Dangles, 2002) and help to stabilize the food web (McCann \& Hastings, 1997; McCann et al., 1998; 
McCann \& Rooney, 2009). If variations in resource availability are small enough, diversity of resources and consumer feeding habits may stabilize ecosystem functioning during times of environmental fluctuations (Yachi \& Loreau, 1999; Loreau, 2000). However, our results suggest that generalist taxa may not be able to maintain ecosystem functioning if resource availability is pushed too low.

\section{Conclusions}

Our results suggest that although $P$. gentilis, Tallaperla spp., and Tipula spp. are all classified in the functional feeding group 'shredders,' they did not respond similarly to resource reduction. Our step-wise reductions in basal resources (leaves, small wood, followed by large wood) showed that obligate leaf shredders were the most sensitive to organic matter reduction (i.e., $P$. gentilis was lost first) and more generalist taxa (Tipula spp. and Tallaperla spp.) were able to use less-preferred food resources such as small wood. The presence of multiple detritivore taxa in our stream, their differing abilities to adapt to changing resource availability, and the presence of wood and amorphous detritus as alternate food resources prevented the immediate collapse of primary consumer production in the exclusion stream. However, with large-scale disturbances to riparian habitats such as ones mimicked by our litter exclusion study, even a more diverse assemblage of detritivorous species likely could not have buffered the loss of ecosystem function observed here. Additional work examining the effects of detrital reductions over a range of magnitudes is needed to develop predictive relationships between the magnitude and quality of organic matter inputs, biodiversity, and ecosystem functioning in the face of riparian disturbance in forested watersheds.

Acknowledgements We thank the technicians and students that assisted with this study. Special thanks to C. Wallace for digitizing many insect gut contents. S. Golladay, A. Rosemond, D. Batzer, M. Moretti, and two anonymous reviewers provided helpful comments that improved this paper. W. Swank, J. Vose, and B. Kloeppel at Coweeta Hydrologic Laboratory provided site support. The National Science Foundation (Grants DEB9207498, DEB-9629268, and DEB-0212315) funded this research.
Data availability All data generated or analzsed during this study are included in this published article and its supplementary information file.

\section{Compliance with ethical standards}

Conflict of interest The authors declare that they have no conflict of interest.

\section{References}

Anderson, N. H. \& A. S. Cargill, 1987. Nutritional ecology of aquatic detritivorous insects. In Slansky Jr., F. \& J. G. Rodriguez (eds.), Nutritional Ecology of Insects, Mites, Spiders, and Related Invertebrates. Wiley, New York: 903-925.

Anderson, N. H., R. J. Steedman \& T. Dudley, 1984. Patterns of exploitation by stream invertebrates of wood debris (xylophagy). Verhandlungen der Internationale Vereinigung für Theoretische und Angewandte Limnologie 22: 1847-1852.

Benke, A. C., 1985. Importance of the snag habitat for animal production in a southeastern stream. Fisheries 10: 8-13.

Benke, A. C., 2018. River food webs: an integrative approach to bottom-up flow webs, top-down impact webs, and trophic position. Ecology 99: 1370-1381.

Benke, A. C. \& J. B. Wallace, 1980. Trophic basis of production among net-spinning caddisflies in a southern Appalachian stream. Ecology 61: 108-118.

Benke, A. C. \& J. B. Wallace, 1997. Trophic basis of production among riverine caddisflies: implications for food web analysis. Ecology 78: 1132-1145.

Benke, A. C., J. B. Wallace, J. W. Harrison \& J. W. Koebel, 2001. Food web quantification using secondary production analysis: predaceous invertebrates of the snag habitat in a subtropical river. Freshwater Biology 46: 329-346.

Couch, C. A. \& J. L. Meyer, 1992. Development and composition of the epixylic biofilm in a blackwater river. Freshwater Biology 27: 43-51.

Cummins, K. W., 1973. Trophic relations of aquatic insects. Annual Review of Entomology 18: 183-206.

Dangles, O., 2002. Functional plasticity of benthic macroinvertebrates: implications for trophic dynamics in acid streams. Canadian Journal of Fisheries and Aquatic Sciences 59: 1563-1573.

Eggert, S. L. \& J. B. Wallace, 2007. Wood biofilm as a food resource for stream detritivores. Limnology and Oceanography 52: 1239-1245.

Eggert, S. L., J. B. Wallace, J. L. Meyer \& J. R. Webster, 2012. Storage and export of organic matter in a headwater stream: responses to long-term detrital manipulations. Ecosphere 3(9): 75.

Fisher, S. G. \& G. E. Likens, 1973. Energy flow in Bear Brook, New Hampshire: an integrative approach to stream ecosystem metabolism. Ecological Monographs 43: 421-439. 
Grubbs, S. A. \& K. W. Cummins, 1996. Linkages between riparian forest composition and shredder voltinism. Archiv für Hydrobiologie 137: 39-58.

Hall, R. O., J. B. Wallace \& S. L. Eggert, 2000. Organic matter flow in stream food webs with reduced detrital resource base. Ecology 81: 3445-3463.

Hax, C. L. \& S. W. Golladay, 1993. Macroinvertebrate colonization and biofilm development on leaves and wood in a boreal river. Freshwater Biology 29: 79-87.

Hoffman, A. \& D. Hering, 2000. Wood-associated macroinvertebrate fauna in central European streams. International Review of Hydrobiology 85: 25-48.

Hutchens, J. J., E. F. Benfield \& J. R. Webster, 1997. Diet and growth of a leaf-shredding caddisfly in southern Appalachian streams of contrasting disturbance history. Hydrobiologia 346: 193-201.

Klug, M. J. \& S. Kotarski, 1980. Bacteria associated with the gut tract of larval stages of aquatic cranefly Tipula abdominalis (Diptera; Tipulidae). Applied and Environmental Microbiology 40: 408-416.

Lawson, D. L., M. J. Klug \& R. W. Merritt, 1984. The influence of the physical, chemical, and microbiological characteristics of decomposing leaves on the growth of the detritivore Tipula abdominalis (Diptera: Tipulidae). Canadian Journal of Zoology 62: 2339-2343.

Loreau, M., 2000. Biodiversity and ecosystem functioning: recent theoretical advances. Oikos 91: 3-17.

Lugthart, G. J. \& J. B. Wallace, 1992. Effects of disturbance on benthic functional structure and production in mountain streams. Journal of the North American Benthological Society 11: 138-164.

Mackay, R. J. \& J. Kalff, 1973. Ecology of two related species of caddis fly larvae in the organic substrates of a woodland stream. Ecology 54: 499-511.

Martin, M. M., J. S. Martin, J. J. Kukor \& R. W. Merritt, 1980. The digestion of protein and carbohydrate by the stream detritivore, Tipula abdominalis (Diptera: Tipulidae). Oecologia 46: 360-364.

McCann, K. \& A. Hastings, 1997. Re-evaluating the omnivorystability relationship in food webs. Proceedings of the Royal Society of London Series B 264: 1249-1254.

McCann, K., A. Hastings \& G. R. Huxel, 1998. Weak trophic interactions and the balance of nature. Nature 395: 794-798.

McCann, K. S. \& N. Rooney, 2009. The more food webs change, the more they stay the same. Philosophical Transactions of the Royal Society of London B: Biological Sciences 364: 1789-1801.

Richardson, J. S., 1991. Seasonal food limitation of detritivores in a montane stream: an experimental test. Ecology 72 : 873-887.

Roeding, C. E. \& L. A. Smock, 1989. Ecology of macroinvertebrate shredders in a low-gradient sandy-bottomed stream. Journal of the North American Benthological Society 8: 149-161.

Rosi-Marshall, E. J. \& J. B. Wallace, 2002. Invertebrate food webs along a stream resource gradient. Freshwater Biology 47: 129-141.

Sinsabaugh, R. L., A. E. Linkins \& E. F. Benfield, 1985. Cellulose digestion and assimilation by three leaf-shredding aquatic insects. Ecology 66: 1464-1471.
Smock, L. A. \& C. E. Roeding, 1986. The trophic basis of production of the macroinvertebrate community of a southeastern U.S.A. blackwater stream. Holarctic Ecology 9: 165-174.

Stewart-Oaten, A., W. W. Murdoch \& K. R. Parker, 1986. Environmental impact assessment: pseudoreplication in time? Ecology 67: 929-940.

Tank J. L., 1996. Microbial activity on wood in streams: Exploring abiotic and biotic factors affecting the structure and function of wood biofilms. Ph.D. Dissertation, Virginia Polytechnic Institute and State University, Blacksburg, Virginia.

Tank, J. L. \& J. R. Webster, 1998. Interaction of substrate availability and nutrient distribution on wood biofilm development in streams. Ecology 79: 2168-2179.

Tank, J. L., J. R. Webster \& E. F. Benfield, 1993. Microbial respiration on decaying leaves and sticks in a southern Appalachian stream. Journal of the North American Benthological Society 12: 394-405.

Tank, J. L., J. R. Webster \& E. F. Benfield, 1998. Effect of leaf litter exclusion on microbial enzyme activity associated with wood biofilms in streams. Journal of the North American Benthological Society 17: 95-103.

Tank, J. L. \& M. J. Winterbourn, 1995. Biofilm development and invertebrate colonization of wood in four New Zealand streams of contrasting pH. Freshwater Biology 34: 303-315.

Tank, J. L. \& M. J. Winterbourn, 1996. Heterotrophic activity and invertebrate colonization of wood in a New Zealand forest stream. New Zealand Journal of Marine and Freshwater Research 30: 271-280.

Wallace, J. B., S. L. Eggert, J. L. Meyer \& J. R. Webster, 1997. Multiple trophic levels of a forest stream linked to terrestrial litter inputs. Science 277: 102-104.

Wallace, J. B., S. L. Eggert, J. L. Meyer \& J. R. Webster, 1999. Effects of resource limitation on a detrital-based ecosystem. Ecological Monographs 69: 409-442.

Wallace, J. B., S. L. Eggert, J. L. Meyer \& J. R. Webster, 2000. Small wood dynamics in a headwater stream. Proceedings of the International Association of Theoretical and Applied Limnology 27: 1361-1365.

Wallace, J. B., J. R. Webster, S. L. Eggert, J. L. Meyer \& E. R. Siler, 2001. Large woody debris in a headwater stream: long-term legacies of forest disturbance. International Review of Hydrobiology 86: 501-513.

Wallace, J. B., S. L. Eggert, J. L. Meyer \& J. R. Webster, 2015. Stream invertebrate productivity linked to forest subsidies: 37 stream-years of reference and experimental data. Ecology 96: 1213-1228.

Webster, J. R. \& J. L. Meyer, 1997. Stream organic matter budgets: an introduction. Journal of the North American Benthological Society 16: 3-13.

White, T. C. R., 1978. The importance of a relative shortage of food in animal ecology. Oecologia 33: 71-86.

Yachi, S. \& M. Loreau, 1999. Biodiversity and ecosystem productivity in a fluctuating environment: the insurance hypothesis. Proceedings of the Natural Academy of Sciences 96: 1463-1466.

Publisher's Note Springer Nature remains neutral with regard to jurisdictional claims in published maps and institutional affiliations. 